\title{
Influence of air temperature on a glacier's active-layer temperature
}

\author{
V. ZAGORODNOV, ${ }^{1}$ O. NAGORNOV, ${ }^{2}$ L.G. THOMPSON ${ }^{1}$ \\ ${ }^{1}$ Byrd Polar Research Center, The Ohio State University, 1090 Carmack Road, Columbus, OH 43210-1002, USA \\ E-mail: zagorodnov.1@osu.edu \\ ${ }^{2}$ Moscow Engineering Physics Institute, 31 Kashirskoe Avenue, 115409 Moscow, Russia
}

\begin{abstract}
Seasonal temperature variations occur in the glacier layer about $15-20 \mathrm{~m}$ below the surface, while at greater depths the glacier temperature depends on the long-term surface conditions. It is generally accepted that for glaciers without surface melting the temperature at $10 \mathrm{~m} \mathrm{depth}\left(T_{10}\right)$ is close to the mean annual air temperature at standard screen level $\left(T_{\mathrm{a}}\right)$, i.e. $T_{10}=T_{\mathrm{a}}$. We found that this relationship is not valid for $T_{\mathrm{a}}$ above $-17^{\circ} \mathrm{C}$ and below $-55^{\circ} \mathrm{C}$. The goal of our investigation is to find a better temperature transfer function (TTF) between $T_{\mathrm{a}}$ and temperature at the boundary of the active layer in accumulation areas of polar and tropical glaciers. Low-precision $T_{10}$ temperatures from boreholes, obtained at 41 sites, are compared with air temperatures $\left(T_{\mathrm{a}}\right)$ measured in the vicinity of these sites for at least a 1 year period. We determine that when $T_{\mathrm{a}}$ falls into the temperature range -60 to $-7^{\circ} \mathrm{C}$, empirical values can be approximated as $T_{10}=1.2 T_{\mathbf{a}}+6.7$. Analysis of these data suggests that high $T_{10}$ occurs in the areas of the glacier that collect meltwater.
\end{abstract}

\section{INTRODUCTION}

The thermodynamic state of a glacier is subject to both seasonal and long-term climatic changes. Temperature distribution in a glacier depends on air temperature, accumulation, solar radiation, clouds, surface albedo, wind, meltwater runoff, percolation and refreezing of meltwater, ice flow and other parameters. On any given glacier, many of these parameters are known with uncertainties. On the other hand, ice cores do not provide the information that would allow us to obtain parameters related to the majority of these surface conditions. Isotopic, ionic and microparticle composition of ice cores represent past atmosphere conditions, while visual stratigraphy (melt features) and borehole temperature are related to the surface net energy balance. Solving the inverse problem (MacAyeal and others, 1991; Dahl-Jensen and others, 1999) has been used in order to reconstruct air temperatures at the glacier surface in the past from deep borehole measurements.

The amplitude of the surface temperature oscillations decreases as $\exp (-x \sqrt{\omega / 2 k})$, where $x$ is the vertical coordinate, $k$ is the thermal conductivity of ice and $\omega$ is the frequency of oscillations at the surface. The penetration depth of seasonal temperature variations, $-h_{\mathrm{al}}$, is determined by the period of variations and the properties of the glacier: density, heat capacity and thermal conductivity (Paterson, 1994). Therefore, daily temperature variations are 20 times smaller at approximately $0.6 \mathrm{~m}$ depth, and the yearly thermal wave penetrates down to $15-20 \mathrm{~m}$, while thermal disturbance can reach $150 \mathrm{~m}$ depth within approximately 160 years (corrected for ice advection). Because most mountain glaciers experience surface melting, their temperature is close to the melting point, and a small fall or rise in air temperature could have a significant impact on the heat- and mass balance at the surface and consequently in the whole glacier within a relatively short period of time.

A theoretical approach to finding temperature in a glacier requires a vast set of data that represent heat transfer at the glacier boundaries. In reality, it is difficult to obtain all the necessary data with the required precision. Furthermore, surface conditions on a glacier vary, causing spatial variations of $T_{10}$. For this reason, the few attempts to find a relationship between $T_{\mathrm{a}}$ and $T_{10}$ at a specific glacier have provided inconclusive results. The most detailed and enduring study of the glacier-climate interaction was performed on White Glacier, Northwest Territories, Canada (Müller, 1976; Blatter, 1987). The 'anomalous' behavior of the high-Arctic valley White Glacier was reported by Müller (1976). On White Glacier, migration of meltwater causes significant changes in surface conditions that complicate temperature transfer function (TTF) determination. The most dramatic changes take place at the equilibrium line.

The first investigation of TTF in accumulation areas of Greenland and Antarctica was conducted by Loewe (1970). In this research, only air temperature and $10 \mathrm{~m}$ borehole data were analyzed. Then Hooke and others (1983) investigated TTF near and below the equilibrium line in the ablation zones of two high-latitude glaciers. They determined the effect of snow cover on ice cooling. In our study, a majority of new datasets do not include mass balance and other meteorological observations and therefore do not permit detailed theoretical investigations. However, our approach demonstrates a good match between $T_{10}$ calculated from air temperatures only and $T_{10}$ measured in a borehole.

Knowledge of the TTF could improve interpretation of the ice-core records, provide estimates of glacier temperature based on weather station data and assist in the prediction of a glacier's response to climate change. Our goal is to investigate TTF in accumulation areas of a relatively large number of glaciers in different regions and find a general relationship between $T_{\mathrm{a}}$ and $T_{10}$. Such an approach is limited by some uncertainty of TTF for glaciers subjected to intense melting and water migration. At the same time, it permits the elimination of local factors (clouds, surrounding topography, meltwater horizontal runoff, etc.) and provides general characteristics of climate-glacier interaction with reasonable accuracy. A general TTF can reveal anomalies in $T_{10}$. The latter is important for study of spatial $T_{10}$ temperature changes induced by climatic variations on ice sheets, meltwater migrations, and aiding in the selection of new icecore drilling sites. This paper presents results of experimental 
and theoretical investigations of the TTF on polar and mountain glaciers, including high-elevation ice caps. A significant portion of cited $T_{10}$ data was acquired in $8-10 \mathrm{~m}$ deep boreholes and therefore may include an additional uncertainty. The paper describes a procedure for deriving the annual mean $T_{\mathrm{s}}$ (surface temperature), $T_{10}$ and $h_{\mathrm{al}}$ (thickness of the active layer or zero annual amplitude depth) based on data from a deep borehole, monthly air temperatures and the physical properties of snow-firn sequences.

\section{THE DATA}

We analyze original data from the accumulation areas at ten sites: five low-latitude and tropical glaciers and five polar sites. In addition, we compiled data from 13 sites new for calculation of the TTF. The majority of data were obtained over the last two decades on glaciers from different climate regimes and from 16 sites where data were collected by Loewe (1970). In order to obtain a general understanding of the glacier-climate interaction and to cover a broad range of $T_{\mathrm{a}}$ under different glacial conditions, we use data collected in the vicinity of boreholes where $T_{10}$ was measured during one or more years.

New Greenland data were obtained in 1998-2000 (Zagorodnov and others, 2000). $T_{\mathrm{a}}$ was measured by the automatic weather station (AWS) near the borehole only for the Dye 2 site. For the other sites (D1, D2 and D3), $T_{a}$ was interpolated using observations from 19 AWSs (Steffen and Box, 2001). Arctic glacier data were obtained from Novaya Zemlya (Chizhov and others, 1968), Franz Jozef Land (Grosswald and others, 1973), Severnaya Zemlya (personal communication from S.M. Arkhipov, 2005) and White Glacier (Müller, 1976; Blatter, 1987). Spatial and temporal changes in $T_{10}$ were studied on Austfonna ice cap on Nordaustlandet (Zagorodnov and others, 1990) and on White Glacier (Müller, 1976; Blatter, 1987). Spatial variations of $T_{10}$ in the accumulation zone of Austfonna ice cap were investigated in 26 shallow and deep boreholes drilled in 1985 and 1987 (Zagorodnov and others, 1990).

Maohuan and others (1982) presented high-altitude glacier data on Altai, Qilian Shan and Himalayan glaciers, obtained in 1964-78. V. Aizen (personal communication, 2005) provided us with the Inylcheck glacier (Tien Shan) data obtained in 2000. Nevado Sajama (Bolivia) 1997, Kilimanjaro (Tanzania) 2000 and Quelccaya (Peru) 2003 borehole temperatures were measured during Byrd Polar Research Center ice-coring expeditions. Air-temperature measurements with AWS at the last three sites were carried out by D. Hardy (personal communication, 2005). All measured $T_{\mathrm{a}}$ and $T_{10}$ temperatures are presented in Table 1.

The majority of $T_{\mathrm{a}}$ and $T_{10}$ data were obtained from the accumulation areas of polar and high-altitude ice sheets and ice caps, where the influence of surrounding mountains and ice dynamics is very small compared to valley glaciers. Only a few sites provided multi-year $T_{\mathrm{a}}$ observations. Because some non-universal instrumental protocols were used to collect meteorological and borehole temperatures, our data are of low precision.

\section{THE MODEL}

In order to determine $T_{10}$, the heat- and mass-transfer problem has to be solved in the snow-firn sequence. The solution is possible when the following boundary conditions are known: the annual air-temperature $\left(T_{\mathrm{a}}\right)$ record, radiation balance at the snow surface and turbulent fluxes of latent and sensible heat. These conditions determine the conductive heat flux that governs the temperature difference between the surface $\left(T_{\mathrm{s}}\right)$ and the bottom of the active layer $\left(T_{\mathrm{al}}\right)$. The typical magnitudes of the mean annual conductive heat flux do not exceed $1 \mathrm{~W} \mathrm{~m}^{-2}$. This value is comparable with the precision of other energy-flux measurements. Thus, determining the temperature in the active layer based on atmospheric heat fluxes is problematic. At the same time, solution of the inverse problem permits the determination of $T_{10}$ based on deep-borehole temperature data.

Since the boundary conditions are unknown, we use the measured temperature-depth profile to solve the heat conduction equation and to find the surface temperature (Nagornov and others, 2001, 2005; Kotlyakov and others, 2004). This is the so-called inverse problem (MacAyeal and others, 1991; Dahl-Jensen and others, 1999). Moreover, we employ the Tikhonov regularization method that minimizes the discrepancy function between measured and calculated temperature in a glacier (Nagornov and others, 2001).

An alternative calculation of $T_{10}$ can be made using the following procedure. A mathematical statement of the problem involves a one-dimensional heat conduction equation determined for the vertical coordinate $z \in(0 ; H)$ at time $t \in\left(0 ; t_{f}\right)$, as well as initial and boundary conditions. Here $H$ is the depth of the borehole and $t_{f}$ is the terminal time which corresponds to the borehole temperature measurements. It is common to use the one-dimensional approach in forward problems (Hooke and others, 1983; Haeberli and Funk, 1991; Suter and others, 2001) to obtain near-surface temperatures on glaciers. As a rule, the contribution of horizontal advection is small due to insignificant horizontal temperature gradients (Haeberli and Funk, 1991). We apply a statement of the forward problem similar to that used by MacAyeal and others (1991). The equations are:

$$
\begin{aligned}
\rho C\left(\frac{\partial T}{\partial t}+w \frac{\partial T}{\partial z}\right) & =\frac{\partial}{\partial z}\left(k \frac{\partial T}{\partial z}\right), & & 0<t<t_{f}, \quad 0<z<H, \\
T(z, 0) & =T_{0}(z), & & 0<z<H, \\
T(0, t) & =T_{s}(t), & & 0<t \leq t_{f}, \\
-k \frac{\partial T(H, t)}{\partial z} & =Q(t), & & 0<t \leq t_{f},
\end{aligned}
$$

where $\rho$ is the density, $C$ is heat capacity, $k$ is the thermal conductivity, $Q(t)$ is the heat flux, $T_{0}(z)$ is initial temperature associated with the temperature in the past and $w$ is the vertical velocity of ice. The coordinate $z=0$ corresponds to the temperature $T_{\mathrm{s}}(t)$. The seasonal surface temperature variations can penetrate only to the specific depth at which temperature is denoted as $T_{\mathrm{al}}$ (Blatter, 1987).

The borehole temperature-depth profile $\theta(z) \equiv T\left(z, t_{f}\right)$ is assumed to be a response to the long-term surface temperature changes $T_{\mathrm{s}}(t)$. The solution to this problem at the terminal time can be rewritten as the operator relationship $\theta(z)=\mathrm{A}\left\{T_{\mathrm{s}}\right\}$. A quasi-solution $\bar{T}_{\mathrm{s}}(t)$ is a function that minimizes the relation

$$
\begin{aligned}
\int_{0}^{H}\left(\mathrm{~A}\left\{\bar{T}_{s}(t)\right\}\right. & -\theta(z))^{2} \mathrm{~d} z \\
= & \min \left[\int_{0}^{H}\left(\mathrm{~A}\left\{T_{\mathrm{s}}(t)\right\}-\theta(z)\right)^{2} \mathrm{~d} z\right] \equiv \alpha,
\end{aligned}
$$


Table 1. Mean annual air-temperature $\left(T_{\mathrm{a}}\right)$ and borehole temperature $\left(T_{10}\right)$ data

\begin{tabular}{|c|c|c|c|c|c|c|}
\hline Station/site & No. in Fig. 1 & $\begin{array}{c}\text { Elevation } \\
\text { ma.s.I. }\end{array}$ & Year & $\begin{array}{l}T_{\mathrm{a}} \\
{ }^{\circ} \mathrm{C}\end{array}$ & $\begin{array}{l}T_{10} \\
{ }^{\circ} \mathrm{C}\end{array}$ & $\begin{array}{c}T_{\mathrm{a}}-T_{10} \\
{ }^{\circ} \mathrm{C}\end{array}$ \\
\hline Plateau, Antarctica ${ }^{1}$ & 1 & 3620 & 1966-68 & -56.4 & -60.5 & -3.9 \\
\hline Vostok, Antarctica ${ }^{1}$ & 2 & 3490 & $1958-67$ & -55.6 & -57.3 & -1.7 \\
\hline Komsomolskaya, Antarctica ${ }^{1}$ & 3 & 3500 & 1958 & -52.2 & -53.9 & -1.7 \\
\hline South Pole, Antarctica ${ }^{1}$ & 4 & 2800 & $1957-67$ & -49.3 & -50.8 & -1.5 \\
\hline Pionerskaya, Antarctica ${ }^{1}$ & 5 & 2740 & $1956-67$ & -38 & -39.4 & -1.4 \\
\hline Charcot, Antarctica ${ }^{1}$ & 6 & 2400 & $1957-58$ & -37.3 & -38 & -0.7 \\
\hline Byrd, Antarctica ${ }^{1}$ & 7 & 1515 & $1957-67$ & -28.3 & -28.3 & 0 \\
\hline Eights, Antarctica ${ }^{1}$ & 8 & 450 & $1964-65$ & -25.9 & -24.8 & 1.1 \\
\hline Ellsworth, Antarctica ${ }^{1}$ & 9 & 43 & $1957-58$ & -23.4 & -24.3 & -0.9 \\
\hline Little America V, Antarctica ${ }^{1}$ & 10 & 42 & $1957-58$ & -22.8 & -23.5 & -0.7 \\
\hline Little America III, Antarctica ${ }^{1}$ & 11 & 30 & $1939-40$ & -23.7 & -23.7 & 0 \\
\hline Camp Century, Greenland ${ }^{1}$ & 12 & 1910 & 1960-63 & -23.5 & -24.5 & -1 \\
\hline Northice, Greenland ${ }^{1}$ & 14 & 2345 & $1953-54$ & -29.9 & -28 & 1.9 \\
\hline Station Centrale, Greenland ${ }^{1}$ & 15 & 2965 & $1949-51$ & -28.2 & -28 & 0.2 \\
\hline Eismitte, Greenland ${ }^{1}$ & 16 & 3000 & 1930-31 & -30.1 & -28.1 & 2 \\
\hline D2, Greenland 2,15 & 17 & 2640 & 1999 & -21.8 & -23.8 & -2 \\
\hline D3, Greenland $d^{2,15}$ & 18 & 2560 & 1999 & -22 & -21.8 & 0.2 \\
\hline D1, Greenland ${ }^{2,15}$ & 19 & 2580 & 1999 & -19.5 & -17.4 & 2.1 \\
\hline Dye2, Greenland ${ }^{2,14}$ & 20 & 2165 & 1998 & -17.8 & -14.8 & 3 \\
\hline White Glacier, northwest Canada ${ }^{3}$ & 21 & 1420 & 1960 & -18 & -8.2 & 9.8 \\
\hline White Glacier, northwest Canada ${ }^{3}$ & 22 & 1420 & 1960 & -18 & -15.5 & 2.5 \\
\hline Qilian Shan, glacier No. 5, China ${ }^{4}$ & 23 & 4500 & 1978 & -8.8 & -5.5 & 3.3 \\
\hline Qilian Shan, China ${ }^{4}$ & 24 & 4600 & 1977 & -11 & -7.3 & 3.7 \\
\hline Himalaya, China ${ }^{4}$ & 25 & 5800 & 1966 & -8.5 & -6 & 2.5 \\
\hline Himalaya, China ${ }^{4}$ & 26 & 6000 & 1964 & -9.5 & -7.7 & 1.8 \\
\hline Inylcheck glacier, Tien Shan, China ${ }^{5}$ & 27 & 5200 & 2000 & -16.3 & -15.1 & 1.2 \\
\hline Aletschgletscher, Swiss Alps ${ }^{6}$ & 28 & 3580 & 1939 & -7 & 0 & 7 \\
\hline Vallée Blanche, French Alps ${ }^{7}$ & 29 & $?$ & $?$ & -8 & 0 & 8 \\
\hline Nevado Sajama, Bolivia ${ }^{8,11}$ & 32 & 6548 & 1997-98 & -10.3 & -10.3 & 0 \\
\hline Kilimanjaro, Tanzania ${ }^{8,12}$ & 33 & 5860 & 2000 & -7 & -1.2 & 5.8 \\
\hline Churlionis ice cap, Franz Josef Land ${ }^{8}$ & 34 & 351 & 1959 & -14 & -9.9 & 4.1 \\
\hline Jackson Ice Cap, Franz Josef Land ${ }^{8}$ & 35 & 441 & 1959 & -14.5 & -4.1 & 10.4 \\
\hline Sedov glacier, Novaya Zemlya ${ }^{9}$ & 36 & 62 & 1959 & -12.3 & -8.4 & 3.9 \\
\hline Ledorazdelnaya, Novaya Zemlya ${ }^{9}$ & 37 & 800 & 1959 & -13.3 & -0.5 & 12.8 \\
\hline Barrier, Novaya Zemlya ${ }^{9}$ & 38 & 300 & 1959 & -10 & -2 & 8 \\
\hline Vavilov ice cap, Severnaya Zemlya ${ }^{17}$ & 39 & 680 & $1976-87$ & -16.6 & -9.5 & 7.1 \\
\hline Austfonna, Nordaustlandet ${ }^{13}$ & 40 & 750 & 1987 & -15.5 & -2.4 & 13.1 \\
\hline Quelccaya, Peru ${ }^{8,16}$ & 41 & 5670 & 2005 & -5 & 0 & 5 \\
\hline
\end{tabular}

Sources: ${ }^{1}$ Loewe (1970); ${ }^{2}$ Steffen and Box (2001); ${ }^{3}$ Blatter (1987); ${ }^{4}$ Maohuan and others (1982); ${ }^{5}$ V. Aizen (personal communication, 2005); ${ }^{6}$ Hughes and Seligman (1939); ${ }^{7}$ Paterson (1994); ${ }^{8}$ D. Hardy (personal communication, 2005); ${ }^{9}$ Chizhov and others (1968); ${ }^{10}$ Grosswald and others (1973); ${ }^{11}$ Thompson and others (1998); ${ }^{12}$ Thompson and others (2002); ${ }^{13}$ Zagorodnov and others (1990); ${ }^{14}$ Zagorodnov and others (2000); ${ }^{15}$ Zagorodnov and others (2002); ${ }^{16}$ Zagorodnov and others (unpublished data); ${ }^{17}$ S.M. Arkhipov (personal communication, 2005).

where the minimum is chosen from continuous function $T_{\mathrm{s}}(t)$. To obtain a stable solution, the Tikhonov method assumes an additional stabilizing term

$$
\Psi\left(T_{\mathrm{s}}\right)=\int_{0}^{H}\left(\mathrm{~A}\left\{T_{\mathrm{s}}(t)\right\}-\theta(z)\right)^{2} \mathrm{~d} z+\beta_{1} \Omega\left[T_{\mathrm{s}}(t)\right],
$$

where $\beta_{1}>0$ is the regularization parameter which must be chosen according to the accuracy of the input data. The additional function

$$
\Omega\left(T_{\mathrm{s}}(t)\right)=\int_{0}^{t_{f}}\left[T_{\mathrm{s}}^{2}+\beta_{2}\left(\frac{\mathrm{d} T_{s}}{\mathrm{~d} t}\right)^{2}\right] \mathrm{d} t
$$

is related to the smoothness of the quasi-solution $\left(\beta_{2}>0\right)$. It has been proved that the procedure of minimization of $\Psi$ is stable with respect to small perturbations of the input data, whereas the minimization of the functional relation (2) does not possess the same property. Therefore, $\Omega$ plays the role of a stabilizer.

The procedure for searching for the minimum of $\Psi$ is based on the iterative gradient method. At the beginning, the zero iteration is defined $\left(T_{\mathrm{s}}\left(t_{0}\right), T_{\mathrm{s}}\left(t_{1}\right), \ldots, T_{\mathrm{s}}\left(t_{k}\right)\right)^{0} \equiv \vec{\mu}^{0}$, where $t_{1}, t_{2}, \ldots, t_{k}$ are nodes. The $n$th iteration is determined as $\vec{\mu}^{n+1}=\vec{\mu}^{n}-\gamma^{n} \operatorname{grad} \Psi\left(\vec{\mu}^{n}\right)$, where $\gamma^{n}>0$ is the gradient step.

We used data from four glacier locations, Kilimanjaro, Nevado Sajama, Vavilov ice cap in Severnaya Zemlya, and South Pole, to find $T_{\mathrm{S}}(z=0)$. Having $T_{\mathrm{s}}$ and the temperature profile for each glacier, we solve the forward problem, taking into account the calculated temperature profile and seasonal variations of air temperature at the surface. Table 2 shows calculated and observed values of $h_{\mathrm{al}}, T_{\mathrm{s}}, T_{\mathrm{al}}, T_{\mathrm{a}}$ and $T_{10}$. 
Table 2. Calculated and observed thermodynamic parameters of the active layer

\begin{tabular}{llcccr}
\hline & \multicolumn{3}{c}{ Calculated } & \multicolumn{2}{c}{ Observed } \\
Glacier & $h_{\mathrm{al}}$ & $T_{\mathrm{s}}$ & $T_{\mathrm{al}}$ & $T_{\mathrm{a}}$ & $T_{10}$ \\
& $\mathrm{~m}$ & ${ }^{\circ} \mathrm{C}$ & ${ }^{\circ} \mathrm{C}$ & ${ }^{\circ} \mathrm{C}$ & ${ }^{\circ} \mathrm{C}$ \\
\hline Kilimanjaro & 14 & -1.32 & -1.15 & -7 & -1.2 \\
Nevado Sajama & 19.9 & -10.10 & -10.81 & -10.3 & -10.3 \\
Vavilov ice cap & 15 & -10.1 & -9.3 & -16.6 & -9.5 \\
South Pole & 15 & -51.1 & -50.37 & -49.3 & -50.8 \\
\hline
\end{tabular}

Calculated temperature at the bottom of the active layer, $T_{\mathrm{al}}$, and temperature measured in boreholes, $T_{10}$, are very close. Derived $h_{\mathrm{al}}$ depth values are noticeably different from the $10 \mathrm{~m}$ depth often used as a lower boundary of the active layer. Nevertheless, a significant difference between $T_{\mathrm{al}}$ and $T_{10}$ is not found. In glaciers with intense summer melting (e.g. Kilimanjaro and Vavilov ice cap), the annual air temperature is relatively low, -17 to $-7^{\circ} \mathrm{C}$, while $T_{10}$ is higher than $T_{\mathrm{a}}$. For the two glaciers where melting is absent or insignificant (Nevado Sajama and South Pole), the calculated and observed temperatures $T_{\mathrm{al}}$ and $T_{10}$ differ by $0.5^{\circ} \mathrm{C}$ or less.

\section{DISCUSSION}

Observed temperatures $T_{\mathrm{a}}$ and $T_{10}$ are shown in Figure $1 \mathrm{a}$, where the thin dashed line represents $T_{10}=T_{a}$; the solid line represents linear regression of observed data $T_{10}=$ 1.2 $T_{\mathrm{a}}+6.7$, and the thick dashed line represents modeled data (Table 1 ) that fit the equation $T_{\mathrm{al}}=1.1 T_{\mathrm{a}}+5.4$. Considering the small number of calculated temperatures $T_{\text {al }}$ used to obtain this equation, the difference between the empirical and calculated equations is less than the precision of the data. Figure $1 \mathrm{~b}$ shows the difference between $T_{\mathrm{a}}$ and $T_{10}$. Because $T_{\mathrm{a}}$ and $T_{10}$ are independently measured variables, the inverse approximation equation can be written as $T_{\mathrm{a}}=0.8 T_{10}-5.8$. The data presented in Figure $1 \mathrm{a}$ and $\mathrm{b}$ demonstrate a relatively large deviation of experimental values. There are several reasons that explain the differences between $T_{10}$ and $T_{\mathrm{a}}$ :

1. Instrumental error in most of the measurements, not exceeding $0.1-0.5^{\circ} \mathrm{C}$;

2. Metrology, i.e. insufficient time for borehole or thermometer equilibration and air circulation in the borehole could cause a $0.1-1.0^{\circ} \mathrm{C}$ difference between real and measured temperatures; insufficient depth for $T_{10}$ measurements results in an uncertainty of up to $0.5^{\circ} \mathrm{C}$;

3. Riming and snow precipitation could restrict air aspiration of the AWS temperature sensors;

4. Changing height of thermometers in AWS due to accumulation/ablation;

5. Meltwater migration; and

6. Cloudiness.

Most of these sources of uncertainty are applicable to all sites. Melting and meltwater migration occur on many alpine and Arctic glaciers. In Figure $1 \mathrm{a}$ and $\mathrm{b}$ the biggest

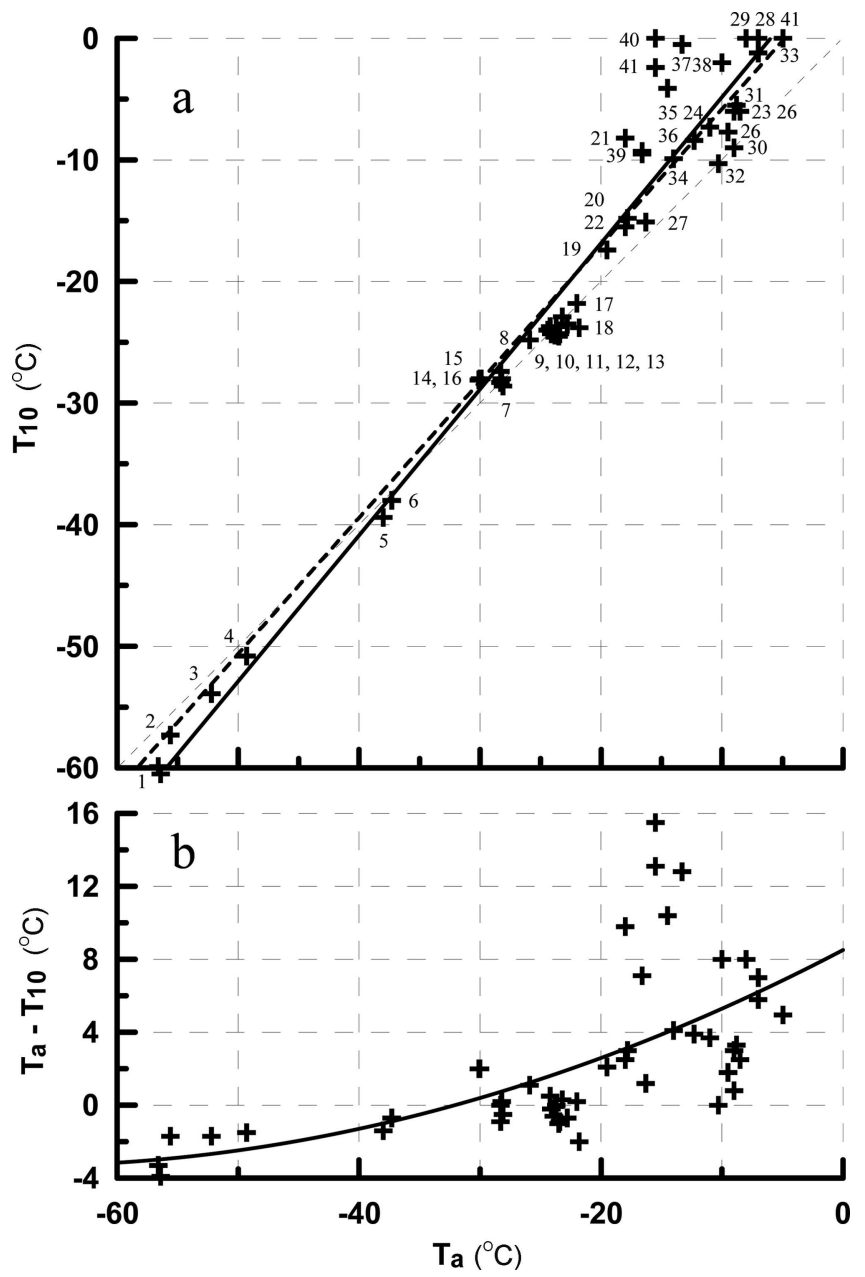

Fig. 1. (a) Measured (crosses; Table 1), modeled (thick dashed line) and approximated (solid line) temperatures $T_{10}$ vs $T_{a}$; thin dashed line is $T_{\mathrm{a}}=T_{10}$. (b) Temperature differences between $T_{\mathrm{a}}$ and $T_{10}$.

data deviation can be attributed to glaciers with intense summer melt: White Glacier; Austfonna (two sites); Jackson Ice Cap, Franz Jozef Land; and summits of Novaya Zemlya ice cap and Vavilov ice cap. The most uncertain relationship between $T_{\mathrm{a}}$ and $T_{10}$ is observed on White Glacier, where at the equilibrium line $T_{10}$ varies between $-17^{\circ} \mathrm{C}$ and $-12^{\circ} \mathrm{C}$ during 1961-64 (Müller, 1976) and from $-19^{\circ} \mathrm{C}$ to $-13^{\circ} \mathrm{C}$ in 1974-81 (Blatter, 1987). Along with instrumental errors in borehole temperatures up to $0.5^{\circ} \mathrm{C}$, variable local conditions along transects cause up to $5-6^{\circ} \mathrm{C}$ uncertainty in $T_{10}$. Müller (1976) used only multi-year averaged $T_{\mathrm{a}}$. Annually averaged data could be used to improve the $T_{10}-T_{\text {a }}$ relationship. White Glacier is a valley glacier, and as such the temperature regime is influenced by topography, mainly due to horizontal meltwater migration. Many researchers attribute spatial and temporal $T_{10}$ changes to the migration of accumulation zones over the glacier slope with the average elevation angle of 1:11 (Müller, 1976).

Less variable conditions were found on the Austfonna ice cap (Zagorodnov and others, 1990) within $2 \mathrm{~km}$ of the summit. Spatial variations of the active-layer temperature were studied here in the visually flat $(100 \times 60 \mathrm{~m}$; average elevation angle $1: 240$ ) accumulation area. In 1985 and 1987 a total of 26 shallow and deep boreholes were drilled, 15 of them in the summit area. In 1985, 2 weeks before the melt season, water-saturated firn was recovered from one 


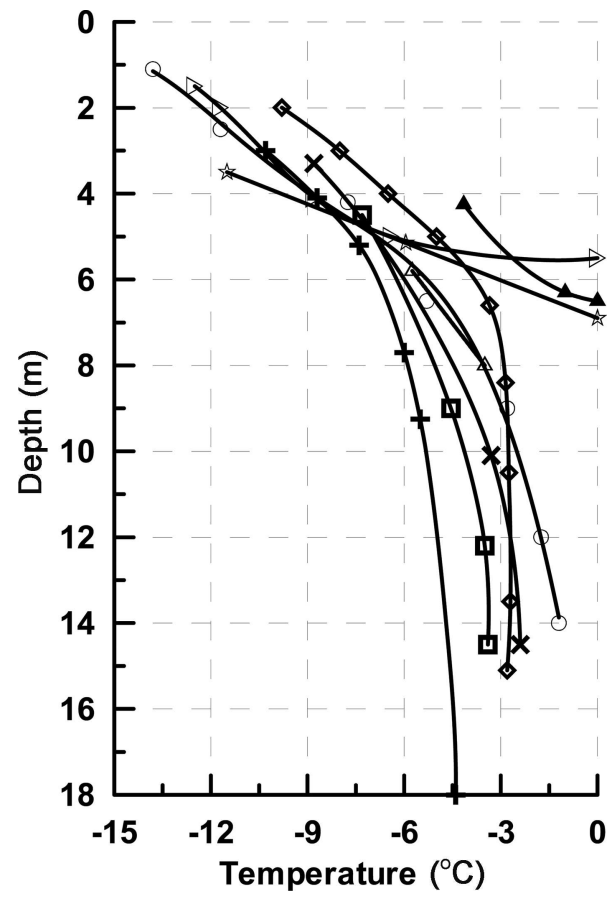

Fig. 2. Borehole temperatures in Austfonna summit area.

borehole at $7 \mathrm{~m}$ depth. During the following melt season, meltwater was found in two other boreholes. Four weeks of observations suggested the presence of meltwater in a subsurface reservoir at the depth of the firn-ice transition. Sub-horizontal channels up to $20 \mathrm{~cm}^{2}$ were discovered in ice cores at 7, 15 and $30 \mathrm{~m}$ depth. Only meltwater can form channels in the firn. In 1987 a network of eight boreholes was drilled in the same area. Figure 2 shows the temperature distribution in those boreholes. Two important findings as illustrated in Figure 2 are: (1) in five boreholes, $T_{10}$ varied between $-1.8^{\circ} \mathrm{C}$ and $-5.0^{\circ} \mathrm{C}$, and (2) melting-point temperatures and water-saturated firn were detected in three of the boreholes. These observations suggest that meltwater was concentrated in a subsurface reservoir above the ice-firn transition and caused a $3.2^{\circ} \mathrm{C}$ rise in $T_{10}$.

Melting in this area was estimated to be $200 \mathrm{~mm}$ w.e. (Zagorodnov and others, 1990). Most of this water was frozen in firn pores, and the rest was concentrated, presumably below the surface, down the slope of elongated valleys. Therefore, $T_{10}=0^{\circ} \mathrm{C}$ was measured in the center of the subsurface valley, while $T_{10}$ was between $-5^{\circ} \mathrm{C}$ and $-3^{\circ} \mathrm{C}$ on its sides and on the ice-cap summit. Accumulation areas of Novaya Zemlya, Severnaya Zemlya and Franz Josef Land ice caps (Chizhov and others, 1968; Grosswald and others, 1973) are among other sites with high $T_{10}$ values, shown in Figure $1 \mathrm{a}$ and $\mathrm{b}$. Intensity of melting on all of the above sites is in the range $160-800 \mathrm{~mm} \mathrm{a}^{-1}$ and correlates well with the summer mean air temperatures (June-August) $\left(T_{\mathrm{s}}\right)$ (Krenke and Khodakov, 1966). In general, $T_{10}$ temperatures on those Arctic glaciers are higher than air temperatures $T_{\mathrm{a}}$ by $5-$ $10^{\circ} \mathrm{C}$. Ohmura (2001) suggests that longwave atmospheric radiation and sensible heat flux are the most dominant (75\%) heat sources responsible for melting.

Contrary to conditions on the Arctic ice caps, $T_{10}$ temperatures in the accumulation zones of the majority of alpine glaciers are only $5^{\circ} \mathrm{C}$ higher than $T_{\mathrm{a}}$. Possibly, lateral runoff of meltwater removes the energy absorbed there.

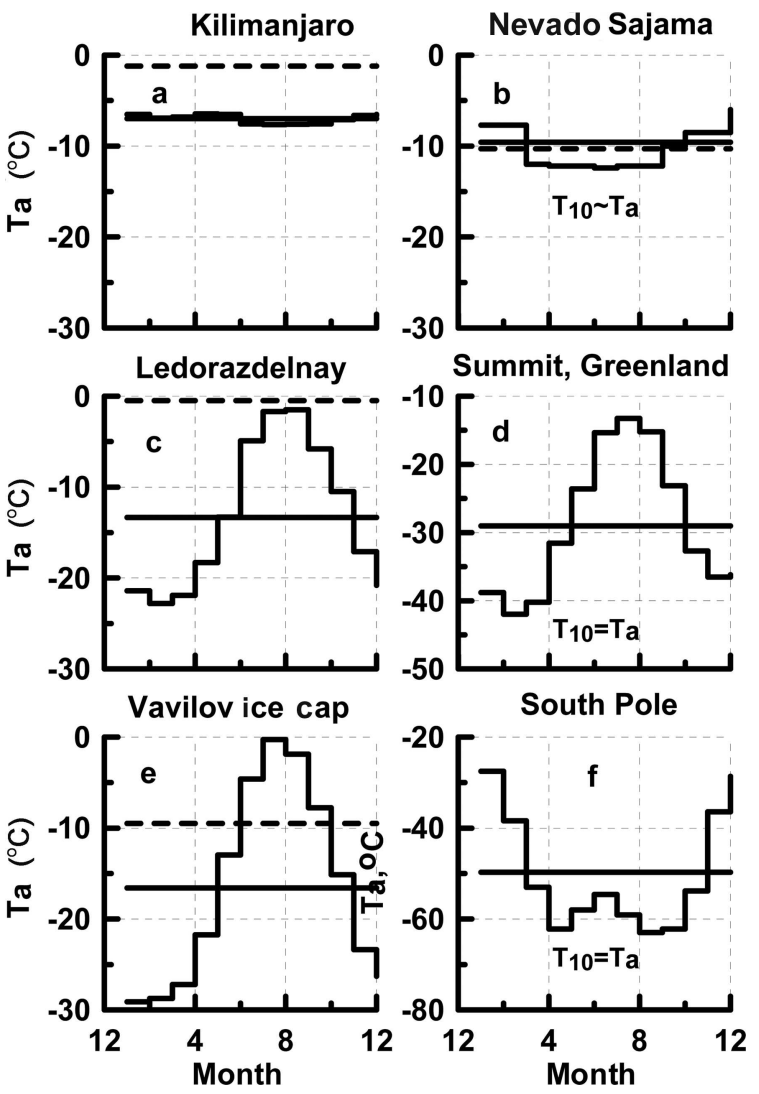

Fig. 3. Monthly and annual mean (solid line) air and borehole $T_{10}$ (dashed line) temperatures at (a) Kilimanjaro (2001-05); (b) Nevado Sajama (1997-98); (c) Novaya Zemlya (1958-59); (d) Greenland (Summit, 1996-2003); (e) Severnaya Zemlya (1978-88); and (f) South Pole (2002).

However, there are not enough data to prove this statement quantitatively. In low-latitude and tropical glaciers, where seasonal variations of air temperature $T_{\mathrm{a}}$ are small (Fig. 3) (Nevado Sajama and Nevado Coropuna), $T_{10}=T_{\mathrm{a}}$. Figure 3 shows monthly average air temperatures $T_{\mathrm{a}}$ and ice temperatures $T_{10}$ in polar, tropical and high-altitude glaciers. These data show that when the mean summer air temperatures are above $-10^{\circ} \mathrm{C}, T_{10}>T_{\mathrm{a}}$. Visual stratigraphy of Nevado Sajama and Nevado Coropuna ice cores shows few ice layers (melt features) that can be attributed to surface melting. Borehole temperatures in Nevado Coropuna boreholes (Fig. 4) are higher than those from Nevado Sajama. The concentration of ice layers in Nevado Coropuna ice cores is higher than in Nevado Sajama cores. In the Nevado Sajama ice cores, the intensity of melting varied from 0 (the year of borehole temperature measurements) to an average of $36 \mathrm{~mm}$ w.e. and as much as $180 \mathrm{~mm}$ w.e. during the last 70 years. According to AWS measurements in 1997, the average air temperature during June-August, $T_{6-8}$, on Nevado Sajama was $-7.1^{\circ} \mathrm{C}$. Using massive Arctic field data, Krenke and Khodakov (1966) developed an empirical equation to calculate intensity of melting: $W=\left(T_{6-8}+10\right)^{3}$. Using AWS data calculations with Nevado Sajama, $T_{6-8}$ data show that the intensity of melting in 1997 is close to $24 \mathrm{~mm}$ w.e. Our stratigraphic studies show that the concentration of melt layers in ice is close to the intensity of summer melting (Zagorodnov, 1985). Lack of signs of melting in the Nevado Sajama 1997 ice core at relatively high summer temperatures suggests that on high-altitude 


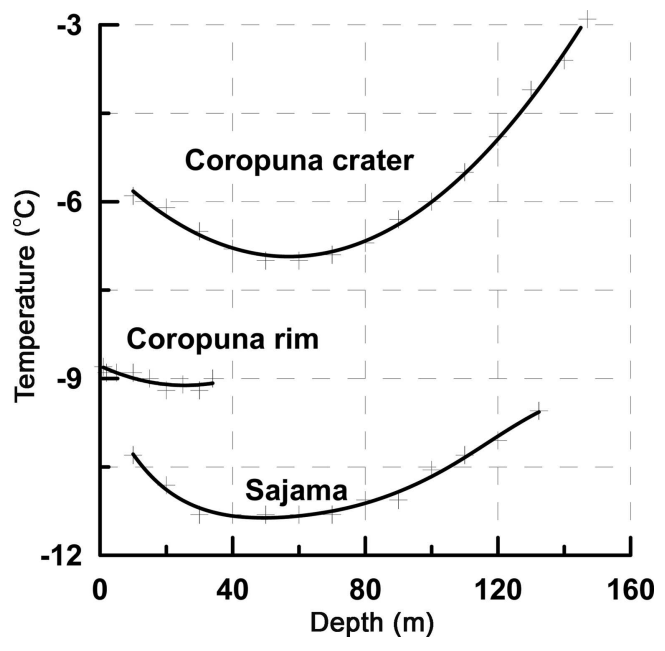

Fig. 4. Nevado Coropuna and Nevado Sajama borehole temperatures.

glaciers sublimation is the dominant mechanism of mass loss. Thus, on high-altitude glaciers the intensive sublimation may prevent ice layer formation at $T_{\mathrm{s}} \approx-7.1^{\circ} \mathrm{C}$. However, the presence of thick ice layers (up to $70 \mathrm{~mm}$, $5 \mathrm{~mm}$ average) in the upper $64 \mathrm{~m}$ (70 years) in the Nevado Sajama ice core indicates warmer conditions with relatively intensive melting in the past. These observations suggest that in tropical and low-latitude glaciers, surface ablation/ melting occurs at $T_{\mathrm{a}} \geq-10^{\circ} \mathrm{C}$.

Ablation on Kilimanjaro may not be dominated by air temperature (Mölg and Hardy, 2004) but rather governed by surface albedo. The key difference between Nevado Sajama and Kilimanjaro glaciers is mass balance. The latter has been losing mass over the last few decades, which has exposed the ice surface between snowfalls, while the former is permanently covered with snow. Consequently, the surface albedo on Kilimanjaro varies between 0.45 (bare ice) and 0.9 (fresh snow) (Mölg and Hardy, 2004), while on Nevado Sajama it is close to 0.85 (fresh and old snow) yearround. Increased precipitation or an air-temperature drop of $3{ }^{\circ} \mathrm{C}$ may drastically increase accumulation and, consequently, the surface albedo on Kilimanjaro and lower the $T_{10}$ temperature. On Kilimanjaro, $T_{10}$ and $T_{\mathrm{a}}$ values match the general TTF. With permanent snow cover on the northern ice field of Kilimanjaro, we would expect that the polar type of TTF $\left(T_{10}=T_{\mathrm{a}}\right)$, similar to Nevado Sajama, would be a better match.

\section{CONCLUSIONS}

The general relationship between annual mean air temperature $\left(T_{\mathrm{a}}\right)$ and the ice temperature at the bottom of the active layer $\left(T_{10}\right)$ is $T_{10}=1.2 T_{\mathrm{a}}+6.7$ (inverse notation: $T_{\mathrm{a}}=$ $\left.0.8 T_{10}-5.8\right) ; T_{\mathrm{a}}$ ranges from $-60^{\circ} \mathrm{C}$ to $-7^{\circ} \mathrm{C}$. At air temperatures between $-55^{\circ} \mathrm{C}$ and $-20^{\circ} \mathrm{C}$, the TTF is $T_{10}=T_{\mathrm{a}}$ (scatter interval $\pm 2^{\circ} \mathrm{C}$ ). Thus, in high-latitude glaciers, sensible surface melting occurs when $T_{\mathrm{a}}$ is above $-17^{\circ} \mathrm{C}$ and results in a $T_{10}$ rise of up to $5-16^{\circ} \mathrm{C}$ above $T_{\mathrm{a}}$. Migration and concentration of meltwater in subsurface reservoirs leads to an additional rise in ice temperatures of $3^{\circ} \mathrm{C}$. In high latitudes, temperate glaciers can exist at mean annual air temperature $T_{\mathrm{a}}$ above $-15^{\circ} \mathrm{C}$. On tropical and low-latitude glaciers a noticeable surface melting occurs at $T_{\mathrm{a}}>-10^{\circ} \mathrm{C}$, below which the TTF is $T_{10}=T_{\mathrm{a}}$. Melting on tropical and low-latitude glaciers can cause a $5{ }^{\circ} \mathrm{C}$ increase in ice temperature $\left(T_{10}\right)$ above $T_{\mathrm{a}}$. Thus, in the tropics and low latitudes, temperate glaciers can exist at $T_{\mathrm{a}}$ above $-7^{\circ} \mathrm{C}$.

\section{ACKNOWLEDGEMENTS}

D. Hardy provided us with unique data from high-altitude glaciers. His work encouraged us to investigate modern climate and glacier interaction more deeply. P. Ginot, P. Wagnon, V. Aizen and J. Box contributed valuable data. This is Byrd Polar Research Center contribution No. 1323.

\section{REFERENCES}

Blatter, H. 1987. On the thermal regime of an Arctic valley glacier: a study of White Glacier, Axel Heiberg Island, N.W.T., Canada. J. Glaciol., 33(114), 200-211.

Chizhov, O.P. and 7 others. 1968. Oledenenie Novoi Zemli [Glaciation of Novaya Zemlya]. Moscow, Nauka.

Dahl-Jensen, D., V. Morgan and A. Elcheikh. 1999. Monte Carlo inverse modelling of the Law Dome (Antarctica) temperature profile. Ann. Glaciol., 29, 145-150.

Grosswald, M.G. and 6 others. 1973. Oledenenie Zemli FrantsaIosifa [Glaciers of Franz Josef Land]. Moscow, Nauka.

Haeberli, W. and M. Funk. 1991. Borehole temperatures at the Colle Gnifetti core-drilling site (Monte Rosa, Swiss Alps). J. Glaciol., 37(125), 37-46.

Hooke, R.LeB., J.E. Gould and J. Brzozowski. 1983. Near-surface temperatures near and below the equilibrium line on polar and subpolar glaciers. Z. Gletscherkd. Glazialgeol., 19(1), 1-25.

Hughes, T.P. and G. Seligman. 1939. The temperature, melt water movement and density increase in the névé of an Alpine glacier. Mon. Not. R. Astron. Soc. Geophys. Suppl., 4(8), 616-647.

Kotlyakov, V.M., S.M. Arkhipov, K.A. Henderson and O.V. Nagornov. 2004. Deep drilling of glaciers in Eurasian Arctic as a source of paleoclimate records. Quat. Sci. Rev., 23(11-13), 1371-1390.

Krenke, A.N. and V.G. Khodakov. 1966. O svyazi poverkhnostnogo tayaniya lednikov s temperaturoy vozdukha [The relationship between surface ice melting and air temperature]. Mater. Glyatsiol. Issled. 12, 153-164.

Loewe, F. 1970. Screen temperatures and $10 \mathrm{~m}$ temperatures. J. Glaciol., 9(56), 263-268.

MacAyeal, D.R., J. Firestone and E. Waddington. 1991. Paleothermometry by control methods. J. Glaciol., 37(127), 326-338.

Maohuan, H., W. Zhongxiang and R. Jiawen. 1982. On the temperature regime of continental type glaciers in China. J. Glaciol., 28(98), 117-128.

Mölg, T. and D.R. Hardy. 2004. Ablation and associated energy balance of a horizontal glacier surface on Kilimanjaro. J. Geophys. Res., 109(D16), D16104. (10.1029/2003JD004338.)

Müller, F. 1976. On the thermal regime of a high-Arctic valley glacier. J. Glaciol., 16(74), 119-133.

Nagornov, O.V., Y.V. Konovalov, V.S. Zagorodnov and L.G. Thompson. 2001. Reconstruction of the surface temperature of Arctic glaciers from the data of temperature measurements in wells. J. Eng. Phys. Thermophys., 74(2), 253-265.

Nagornov, O.V., Y.V. Konovalov and V. Tchijov. 2005. Reconstruction of past temperatures for Arctic glaciers subjected to intense subsurface melting. Ann. Glaciol., 40, 61-67.

Ohmura, A. 2001. Physical basis for the temperature-based meltindex method. J. Appl. Meteorol., 40(4), 753-761.

Paterson, W.S.B. 1994. The physics of glaciers. Third edition. Oxford, etc., Elsevier. 
Steffen, K. and J. Box. 2001. Surface climatology of the Greenland ice sheet: Greenland Climate Network 1995-1999. J. Geophys. Res., 106(D24), 33,951-33,964.

Suter, S., M. Laternser, W. Haeberli, R. Frauenfelder and M. Hoelzle. 2001. Cold firn and ice of high-altitude glaciers in the Alps: measurements and distribution modelling. J. Glaciol., 47(156), 85-96.

Thompson, L.G. and 11 others. 1998. A 25,000-year tropical climate history from Bolivian ice cores. Science, 282(5395), 1858-1864.

Thompson, L.G. and 10 others. 2002. Kilimanjaro ice core records: evidence for Holocene climate change in Tropical Africa. Science, 298(5593), 589-593.

Zagorodnov, V.S. 1985. Ldoobrazovaniye i glubinnoye stroyeniye lednikov [Ice formation and inner structure of glaciers]. In
Kotlyakov, V.M., ed. Glyatsiologiya Shpitsbergena [Glaciology of Spitsbergen]. Moscow, Nauka, 119-147.

Zagorodnov, V.S., S.A. Sin'kevich and S.M. Arkhipov. 1990. Gidrotermicheskiy rezhim ledorazdel'noy oblasti Vostochnogo ledyanogo polya, o. Severo-Vostochnaya Zemlya [Hydrothermal regime of the ice-divide area of Austfonna, Nordaustlandet]. Mater. Glyatsiol. Issled. 68, 133-141.

Zagorodnov, V., L.G. Thompson and E. Mosley-Thompson. 2000. Portable system for intermediate-depth ice-core drilling. J. Glaciol., 46(152), 167-172.

Zagorodnov, V.S., L.G. Thompson, E. Mosley-Thompson and J.J. Kelley. 2002. Performance of intermediate depth portable ice core drilling system on polar and temperate glaciers. Natl. Inst. Polar Res. Mem., 56, Special Issue, 67-81. 